\title{
ACCEPTANCE TOWARD CHILDREN AND FATHERING IN CARING FOR CHILDREN WITH HEARING IMPAIRMENT
}

\author{
Starry Kireida Kusnadi, Ardianti Agustin \\ Faculty of Psychology, Wijaya Putra University \\ Jl. Raya Benowo 1-3 Surabaya, Indonesia 60197 \\ starrykusnadi@uwp.ac.id
}

\begin{abstract}
The purposes of this research are to observe acceptance toward children and father role in caring for children with hearing impairment. Acceptance is someone's process in accepting reality, accept others as they are overall, have a positive gesture toward others, admit and accept various aspects, including the bad and good qualities. Father who fully involved in caring children will give positive impacts on whole aspects of child development. This research applies to the quantitative method. The scale used is acceptance toward children scale and father involvement scale. The subjects in this research are 37 father who has children with hearing impairment. Research result shows that there is a significant relation between acceptance toward children and father involvement in caring for children with hearing impairment $(\mathrm{r}=0,948 ; \mathrm{p}<0,001)$. Therefore, the higher the acceptance toward children with hearing impairment is, the higher the fathering involvement can be concluded.
\end{abstract}

Keywords: self-acceptance, the role of fostering (fathering); deaf children (children with hearing impairment)

\begin{abstract}
Abstrak
Tujuan penelitian ini untuk melihat bagaimana penerimaan terhadap anak dan peran seorang ayah dalam mengasuh anak tunarungu. Penerimaan adalah proses seseorang dalam menerima kenyataan yang ada, menerima orang lain apa adanya secara keseluruhan, memiliki sikap yang positif terhadap orang lain, mengakui dan menerima berbagai aspek termasuk kualitas baik dan buruknya. Ayah yang terlibat penuh dalam pengasuhan anak akan memberikan dampak positif pada seluruh aspek perkembangan anak. Penelitian ini menggunakan metode kuantitatif. Skala yang digunakan adalah skala penerimaan terhadap anak dan skala keterlibatan ayah. Subjek dalam penelitian ini 37 ayah yang memiliki anak tunarungu. Hasil penelitian menunjukkan terdapat hubungan yang signifikan antara penerimaan terhadap anak dengan keterlibatan ayah dalam mengasuh anak tunarungu $(\mathrm{r}=0,948 ; \mathrm{p}<0,001)$. Dengan demikian, dapat disimpulkan bahwa semakin tinggi penerimaan terhadap anak tunarungu, semakin tinggi pula keterlibatan ayah dalam mengasuh anaknya.
\end{abstract}

Kata kunci: Penerimaan terhadap anak; peran ayah mengasuh (fathering); anak tunarungu

\section{INTRODUCTION}

Birth of a child in a family is a wonderful event, and even the child is said to become one of the factors that influencing marriage stability (Hurlock, 2014). When a mother conceiving, surely she expects that the child in the womb born health and complete. Since the child conceived, parents try to imagine and illustrate the child physically and start to design things they can do to give the best for the child. Not all child born to fit in parent's expectation and dream. Not all child born with health and complete conditions, some of them born with limitations or disability, physically and psychologically. Non-expert addresses them as disabled people.

A deaf person is a person who experiences flaws or loses hearing ability partly or entirely, 
caused by the malfunction of hearing instrument, partly or entirely, so he/ she can not make use of hearing aid in daily life. That condition has a complicated impact on life (Handayani, Priyono \& Anwar 2017). That matter impacts on the complicated life, especially in language ability as an essential communication tool. The impairment in hearing, experienced by deaf children, and it causes child language development delay. Then it influences critical development in communicating with others. Communicating with others requires clear articulation and language so that the message can be delivered well and have one meaning with the result there no meaning misinterpretation.

Deaf child is an individual who experiences losing or lacking hearing ability, partly or entirely, caused by hearing instrument partly or entirely malfunction, so that can not make use of hearing instrument in daily life that have an impact on complicated life (Septiani, Meiyani, \& Assjari 2010). Based on that idea, we can conclude, someone with a hearing impairment which covers all light gradation, moderate and severe can be grouped in two types, heard less and deaf, which can disrupt gaining information and language process as a communication tool. The dimension of hearing impairment affects communication skill in daily life, especially speech ability with clear and correct articulation. Precise articulation usage will simplify others understanding toward message delivered.

Through an interview method on deaf children's parents, shows that sometimes deaf children experience difficulty in communication. Hearing impairment on deaf children causing, in general, they experience the perceptual disorder, speech and communication disorder, cognitive disorder, social and emotional disorder, educational problems, intellectual disruption and vocational problems (Solikhatun, 2013).
Hearing loss on deaf children classified into five; First, deaf children with 20-30 dB hearing loss (slight losses). Second, are deaf children with 30-40 dB hearing loss (mild losses). Third, are deaf children with 40-60 $\mathrm{dB}$ hearing loss (moderate losses. Fourth, are deaf children with 60-75 dB hearing loss (severe losses). Fifth, deaf children with 75 $\mathrm{dB}$ hearing loss (profoundly losses) (Wasito, Sarwindah \& Sulistiani, 2012). Children born with deaf condition can cause parents to feel depressed, disappoint, and can not believe so that parents often treat children poorly. The relations problem will need extra attention from parents and family members.

Fathering is indispensable in childcare, which can bring a positive impact later on toward child life. Fathering has an effect on cognitive, emotional, social development even will take effect on lowering negative child development. We can conclude that father involvement can bring a positive effect on child development such as children's cognitive, emotional and social development (Allen \& Daly, in Lismanda, 2017).

During children development, father role in general, give more spirit to children to be more independent. Father, for example, let the children cross the road by themself, let the children go far from home, visiting a neighbour and other things that trained since early childhood (Dagun, 2013). Father's presence in a family can be a model for children in perseverance, achievement motivation. Father can be a successful model for children. When children have much opportunity to observe and imitate, the father's gesture will help in developing problemsolving ability (Dagun, 2013).

Research by Walton \& Lindgren (in Dagun, 2013) shows that children with less care and attention from father experience lame and decreasing in academic ability, stunted social 
activity, and limited social interactions. Moreover, in male children, masculinity characteristic owned becomes blurred.

According to Wijanarko, and Setiawati (2016), parenting by father will be different from parenting by mother. Father whom masculine will educate children in practical ways and slightly involving affection such as caress, language contact with children and teasing. According to Dagun (2013), children's independent behaviour who taken care of father, in general, will be higher compared to children who take care by mother. Children who take care by father tend to be more independent, confident, like challenging games and exploration. Fathering also develop the ability to empathize, attentive, and affection also have better social relation (Andayani \& Koentjoro, 2004, in Bussa, Kiling-Bunga, Thoomaszen, \& Kiling 2018). However, children who take care by their father usually tend to lack understanding of other, untidy, and tend to like process over result.

Deaf children have characteristic and different development problem from normal children in general. Speech and language development are the main problem experienced by deaf children. Other than that, there are some other development problems, such as cognitive, emotional, social and behaviour development. Cognitive development in general, deaf children's intelligence is the same as normal children's, but development functional affected by speech ability level, limited information, and abstraction power, so that deafness obstruct the attainment of broader knowledge process. On emotional development, lack of spoken and written language understanding, often causing negative or incorrect interpretation by deaf children and be a pressure for emotion. Emotion pressure can prevent personal development by showing selfclosing attitude, acting aggressive or otherwise showing indecision and hesitance. When the deaf children greeted by stranger will look restless and nervous. On social development, human as social being always need togetherness with others. As well as deaf children, he can not be separated from that need. Social and cultural factors, covers a broad understanding such as an environment where children interact between individuals, groups, family members and society. For the benefit of deaf children, all family member, teachers and surrounding society should try to learn and understand deaf children condition, because that matter can help detain negative personality development of deaf children. On behaviour development, personality development much determined by childrenparent's relationship. (Sutjihati, in Wasito, et al., 2012).

Fathering can be explained as a role played in task to direct the children to become independent in their adult-life., physically and biologically. Father's role is just as important as the mother's role and influences children development, although in general spend less time compared to the mother's. That because according to Yuniardi (in Marhamah \& Febrialismanto, 2017) father's love based on certain conditions, different from mother's unconditional love. Therefore, the father's love motivates children to appreciate values and responsibilities.

According to Erawati (in Fox \& Bruce, 2001; Lestari, Nursetiawati, \& GP 2015) put forward thick fathering concept with Parental Investment Theory (PIT) perspective. Parental Investment Theory (PIT) measured by; 1. Responsivity: father's quantity in using the warmth of affection and supportive gesture. This component is covering father's understanding to provide children's needs, including providing financial resources for children, planning and managing children' life. In this dimension, the father asked to interact directly with children, in mind, affection and 
planning for children. 2. Harshness: father's quantity with a fierce attitude, punishment and inconsistent approach. This component covers the father's gesture in applying firmness, father's presence and availability for children. 3. Behavioural Engagement: father's quantity in children activities involvement. This component covers the father's experience with children in direct contact and interaction in the form of caring, playing or spending spare time. 4. Affective Involvement: a father is in wanting and loving for the children. This component presenting time spending by father indirect interaction with children and not covers time spending in father- children closeness, as a father's form of recognition for their child's presence.

Family environment have an important and strong influence toward children development especially for deaf children (Sirait, Suriadireja \& Sudiarna, 2016). Deaf children experiencing obstacles that make then difficult to accept environment's norms. The deaf children's success in carry out the task very depend on family guidance and influence. It is not easy for parents to accept reslity that their children suffer from disabilities. Parent's first reaction when they find out that their children is deaf, they felt devastated and confused. Parent's gestures have a big influence to deaf children's personality development. Unsupportive gestures can obstruct children development, such as protecting or ignoring.

According Hurlock (in Santoso, Wibhawa \& Ishartono, 2018), acceptance by family means as parent's acceptance that is a psychological effect and parent's gesture such as affection, clinging, concern support and caring, parent can feel and express their love to their children. Family acceptance is a success index used by someone to play a role in social group and show other group member's liking level to cooperate and play together.
Yusuf (in Benny, Nurdin \& Chandrayetti, 2014) reveal that family acceptance is a family ability and eagerness level to live with all characteristic inside. Accepting family member mean as a family that does not have problem, does not have burden of feeling toward family, so the family will have more opportunity adapting with society. Family acceptance ability covers ability to accept others at least, patient, calm, courteus.

According to Rogers (in Anggraini, 2013), acceptance is someone gesture to accept others as they are complete, without condition or judgement followed. The parent who accepts their children will be put their children on an essential position in the family and developing warm emotional relation with children, such as get involve with the children, pay attention to child's agenda and goals. Parent's acceptance aspects such get involved with children, pay attention to child's agenda and goals, show affection, have shown an effort in providing physical and psychological need, have a good dialogue with children, accept children as a person, give guidance, support and motivation, sample, and not over-demanding (Hurlock, 2014). When acceptance exists in a family, it can help parents in caring and support children development. The level of acceptance by the family will affect on family relation quality. Parent's acceptance does not only apply to mothers, even though the task to care for children is identical to the mother's or woman's task, all this time. Madsen stated that woman's task is to take care of the residential area, take care of husband and children (in Dewi, Margaretha, \& Wibhowo 2014). While social and financially dependent on husband or man. So, no wonder if man or husband is preoccupied with their job (in Dewi et al., 2014).

Family is the first and primary place for deaf children's growth and development. If the 
environment in the family is excellent and delightful, the children will grow well. However, if it not so, children's development will be obstructed. Every child must be wishing to be accepted by the parent and not demanded to fulfil the parent's goals. Children will be happy if accepted and have affection given by their parents. On the other side, when children underestimated, wronged, or having less affection from parents will tend to withdraw. Parent's acceptance has a significant meaning for positive self-concept building, self-confidence, able to adjust so when children are on the environment such as school or society, they will be able to selfactualizing (Kusnadi \& Agustin, 2019)

Based on research results by Faradina (2016), parental acceptance of children with special needs has steps and aspects in accepting. Some steps passed by three subjects in the acceptance reaching process toward their children diagnosed with special needs and three subjects go through different stages caused by different child' conditions.

Research result by Anggarini, Hartiti and Rosidi (2011) on six informants who have an autistic child in SLB Negeri Semarang, resulting in that parent first reaction toward autistic diagnosed children are depressed, stressful, cry, and denying the doctor's diagnose that state their children have diagnosed with autistic.

Research result by Devina and Penny (2016) shows that the self-acceptance process by the three parents ends to vary. The three participants went through five phases disclosed by Kubler-Ross; Denial, Anger, Bargaining, Depression, Acceptance. The five phases not always move forward, sometimes move backward or occur with other phases.

Research result by Febrianto and Darmawanti (2016) shows that the three participants can accept their children whom autistic diagnosed through some acceptance stages. The three participants have in common regarding early reactions when finding out diagnosis results, three participants also experiencing anger for the negative views from others toward their children. The three participants do not only have common but also the three different way in support by the big family. A positive view of the family can make the father more confident in facing children's problems. On the other side, when the family has a negative response toward the children's condition, the father will tend to distraught and comparing with other families.

Based on the background mentioned above, researcher interested in researching acceptance toward children and fathering in caring for children with hearing impairment.

\section{METHOD}

Population in this research are parents with deaf children in SDLB B Karya Mulia I Surabaya. The subject in this research consists of 37 fathers with deaf children. The sampling technique used is Purposive Sampling Technique. Respondents consist of 37 fathers who have deaf children in SDLB B Karya Mulia I Surabaya.

The instruments used in the research were the Child Acceptance Scale in caring for deaf chidren (25 items, $\alpha=.810$ ) and the Father's Involvements Scale (30 items, $\alpha=.815$ ). Five points Likert scale was used, and it ranges from Strongly Agree (SA), Agrees (A), Hesitant (H), Disagrees (DA), to Strongly Disagree (SDA). Acceptance scale toward children was arranged based on Hurlock theory (2014) with aspects, and the aspects are: 1). involved with children; 2). pay attention to child's agenda and goals; 3). expressing affection; 4). have a good dialogue with children; 5). accept children as a person; 6). 
give guidance and motivation; 7). give a good example; and 8). not over-demanding. Item's examples for acceptance scale toward children are "I play with children when at home" and "asking children goals when they have grown up". The fathering scale was developed based on a thick fathering concept with the Parental Investment Theory (PIT) perspective, with aspects of 1). responsiveness; 2). harshness; 3). behavioral engagement; and 4). affective involvement. The examples for fathering scale are "I will hug my children when they are sad" and "I will give punishment when they make mistakes".
The data was analyzed with Product Moment Correlation using SPSS (Statistical Package for Social Science) Program, Windows 20 series.

\section{RESULTS AND DISCUSSION}

In this research, there are two quantitative data resulted; child acceptance scale's score and fathering scale's score. As for there are 23 fathers who have high child acceptance score and high fathering score.

Tabel 1.

Description of Child Acceptance Hypothetical Variable Data

\begin{tabular}{ccccc}
\hline Score Max & Score Min & Mean & Range & SD \\
\hline 125 & 25 & 75 & 100 & 16,7 \\
\hline
\end{tabular}

Tabel 2.

Child Acceptance Variable Categorization

\begin{tabular}{cccc}
\hline Category & Range & Frequency & Percentage \\
Very Low & $\mathrm{X} 75,00$ & 0 & 0 \\
Low & $75,01<\mathrm{X} 91,71$ & 2 & 5 \\
Moderate & $91,72<\mathrm{X} \mathrm{108,42}$ & 10 & 27 \\
High & $108,43<\mathrm{X} 125,13$ & 23 & 62 \\
Very High & $\mathrm{X}>125,13$ & 2 & 5 \\
\hline
\end{tabular}

Based on Table 2, it shows that Child Acceptance Variable moves from moderate (27\%), 23 Subjects in High Category (62\%), to High. Ten Subjects in Moderate Category acceptance toward deaf children.

Tabel 3.

Description of Father's Involvement Hypothetical Variable Data

\begin{tabular}{ccccc}
\hline Score Max & Score Min & Mean & Range & SD \\
\hline 150 & 30 & 90 & 120 & 25 \\
\hline
\end{tabular}

Tabel 4.

Father's Involvement Variable Categorization

\begin{tabular}{cccc} 
Category & Range & Frequency & Percentage \\
\hline Very Low & X 90,00 & 0 & 0 \\
Low & $90,01<$ X 115,01 & 1 & 3 \\
Moderate & $115,02<$ X 140,02 & 11 & 30 \\
High & $140,03<$ X 165,03 & 23 & 62 \\
Very High & $X>165,03$ & 2 & 5 \\
\hline
\end{tabular}


Based on the categorization table above, it shows that all subject's category on the father's involvement variable tends to move from moderate to high. Eleven subjects in the Moderate category (30\%), 23 subjects in the High category (62\%), means that father's involvement in deaf children caring, relatively high.

Based on the research result, we can explain that 37 fathers already have High Child Acceptance Score. It shows that fathers can accept their children as they are entire, without condition and judgment applied. Fathers get involved with children, pay attention to children's agenda and goal, show affection, having a good dialogue with children, accept children as a person, give guidance, support, motivation, good example, and do not overdemanding.

Beside children acceptance, father's involvement also has a high score. It shows that the fathers take part in doing their tasks to direct children become independent in their adulthood, physically and psychologically. Fathers who have Responsivity, they show affection, loving, and supportive gesture, On the other side, fathers who have Harshness gesture will be fierce, punishing, and have an inconsistent approach. Fathers who also have Behavioral Engagement gesture will be involved in children activities, and fathers who have Affective Involvement gesture will wanting and caring for the children (Fox \& Bruce, in Lestari, 2015).

High acceptance toward children can help in caring and will support the child's development. Father will take part to do their task in directing their children, physically and psychologically. On the other side, if children acceptance is low, it will obstruct a child's caring and effect in a child's development.
Quantitative data result processed using parametric statistical with Product Moment correlation technique. The argument for using the parametric statistical method is the number of subject $\geq 20$ person, and parametric assumption tests are fulfilled.

Based on the result of this study, the researcher can show that there is a relationship between child acceptance and father's involvement in caring for deaf children. Based on the correlation coefficient rate; $r=0,948$ and $p<$ 0,001 , which have a positive correlation rate, means the higher acceptance toward children will be followed with higher fathering in caring deaf children. The higher the child acceptance, the higher the father's involvement in caring for deaf children too. Father will accept children's condition as they are, get involved with children, give attention to children's goals, show affection, good dialogue with children, give guidance and motivation, give good examples, and not over-demanding. Besides that, fathers will take part in doing their tasks to direct their children to become independent in their adulthood, physically and psychologically. Father will have a responsivity gesture; for example, a father will show warmth, affection and supportive gesture. On the other side father also have harshness gesture, punishing and inconsistent approach, fathers also have behavioural engagement gesture, where father get involved in children's activity, other than that father will have affective involvement gesture like father wanting and loving their children.

These results are in line with previous research by Septiani and Nasution (2017). She states that there is a relation between children's moral intelligence development with the role of a father's involvement in caring for deaf children. Moreover, the contribution of influence from the father's involvement toward children's moral intelligence development is as significant as $36 \%$. 
Research result by Hidayati, Kaloeti and Karyono (2011) describes the parenting process involving fathering. There are three main goals in various parenting research, specifically children's health, and safety, preparing children to live a productive life in their adulthood and be able to transmit cultural values. Therefore, a good and quality relationship between children and parents is essential for children's growth and development.

Research results by Zuhairah \& Tatar (2017) stating that the higher father's involvement in caring is, the lower the delinquency in teenagers will be, and vice versa. Therefore, it can be concluded that teenagers who reported high father's involvement in caring may decrease delinquency rates in teenagers'.

Research results by Ayuningrum (2019) suggest that the higher father's involvement in fathering is, the better the children' independence becomes. Meanwhile, research result by Harmaini, Shofiah \& Yulianti (2014) shows that affection support and caring support are more dominant in a way father caring for their children. This matter is a sign that children's success in the future is more determined by the power of affection, support and fathering support. Affection support and fathering, from father's perspective, are in the form of psychological caring, character building. This result may be influenced by cultural values' views and demands of social norms.

\section{CONCLUSION}

Based on the research result, we can conclude that there is a relation between acceptance toward children and fathering in caring for children with hearing impairment.

\section{REFERENCES}

Anggarini, Dwi S., Hartiti T \& Rosidi A. (2011). Studi fenomenologis tentang penerimaan orangtua terhadap anak autis di slb negeri semarang. Jurnal Keperawatan, 4(1), 1-15. https://jurnal.unimus.ac.id/index.php/F IKkeS/article/view/1847/1889.

Anggraini, R.R. (2013). Persepsi orangtua terhadap anak berkebutuhan khusus (deskriptif kuantitatif di SDLB N.20 Nan Balimo Kota Solok). Jurnal Ilmiah Pendidikan Khusus, 2(1), 258265.

http://ejournal.unp.ac.id/index.php/jupe khu/article/view/951/807.

Ayuningrum, D. (2019). Hubungan keterlibatan ayah dalam pengasuhan anak dengan kemandirian. Jurnal Inovatif Ilmu Pendidikan, 11(1), 6782.

http://jurnal.fkip.unila.ac.id/index.php/ JIIP/article/view/18019.

Benny, F., Nurdin, A.E., \& Chundrayetti, E. (2014). Penerimaan ibu yang memiliki anak retardasi mental di SLB YPAC Padang. Jurnal Kesehatan Andalas, $3(2)$, 159-162. http://jurnal.fk.unand.ac.id/index.php/j ka/article/view/72/67.

Bussa, D.B., Kiling-Bunga, B.N., Thoomaszen, F.W., \&Kiling. I.Y. (2018). Persepsi ayah tentang pengasuhan anak usia dini. Jurnal Sains Psikologi, 7(2), 126-134. DOI : http://dx.doi.org/10.17977/um023v7i2 2018 p126.

Dagun, S. M. (2013). Psikologi keluarga. Jakarta: PT. Asdi Mahasatya. 
Devina, G., \& Penny, H. (2016). Gambaran proses penerimaan diri ibu yang memiliki anak disleksia. IJDS: Indonesian Journal of Disability Studies, $\quad 3(1), \quad$ 44-52. https://ijds.ub.ac.id/index.php/ijds/arti cle/view/33/30.

Dewi C, Margaretha N., \& Wibhowo C. (2014). Proses penerimaan ayah terhadap anak penderita down syndrome. Jurnal Unika Psikodimensia. 13(2). DOI: 10.24167/psiko.v13i2.264.

Febrianto, A.S., \& Darmawanti, I. (2016). Studi kasus penerimaan seorang ayah terhadap anak autis. Jurnal Psikologi Teori dan Terapan, 7(1), 50-61. DOI: 10.26740/jptt.v7n1.p50-61..

Fox, G.L., \& Bruce, C. (2001). Conditional fatherhood: identity theory and parental investment theory as alternative sources of explanation of fathering. Journal Marriage and Family, 63(2), 394-403. DOI: $10.1111 / \mathrm{j} .1741-$ 3737.2001.00394.x.

Handayani, E. S., Priyono \& Anwar M. (2017). Peningkatan pemahaman dongeng anak tunarungu melalui simulation based learning. Indonesian Journal of Disability Studies (IJDS), 4(1), 9-15. 10.17509/pedagogia.v15i2.8093.

Harmaini, H., Shofiah, V., \& Yulianti, A. (2014). Peran ayah dalam mendidik anak. Jurnal Psikologi, 10(2), 80-85. DOI: http://dx.doi.org/10.24014/jp.v10i2 .1184 .

Hidayati, F., Kaloeti, D.V.S., \& Karyono. (2011). Peran ayah dalam pengasuhan. Jurnal Psikologi Undip, 9(1), 1-10. https://ejournal.undip.ac.id/index.php/psi kologi/article/view/2841.
Hurlock, E. B. (2014). Perkembangan Anak Edisi Keenam Jilid I. Jakarta : Erlangga Press.

Kusnadi, S. K., \& Agustin, A. (2019). Parental emotional coaching untuk meningkatkan gaya pengasuhan dan penerimaan orang tua terhadap anak tunarungu. Jurnal Psikologi Teori dan Terapan. 9(2), 148159. DOI: 10.26740/jptt.v9n2.p148-159.

Lestari, W., Nursetiawati, S., \& GP, U.V (2015). Hubungan antara keterlibatan ayah dengan pembentukan karakter pada remaja. Jurnal Kesejahteraan Keluarga dan Pendidikan, 2(1), 36-43. DOI: https://doi.org/10.21009/JKKP.021. 06.

Lismanda, Y. F. (2017). Pondasi perkembangan psikososial anak melalui peran ayah dalam keluarga. Jurnal Pendidikan Islam, 2(2), 89-98. http://riset.unisma.ac.id/index.php/fai/arti cle/view/826/1118.

Marhamah, N. R., \& Febrialismanto. (2017). Gambaran peran ayah dalam pengasuhan anak usia 5-6 tahundi taman kanak-kanak aisyiyah bustanul athfal $\mathrm{v}$ kecamatan bukit raya kota pekanbaru. Jurnal Online Mahasiswa Bidang Keguruan dan Ilmu Pendidikan. 4(1), 1-13. https://jom.unri.ac.id/index.php/JOMFKI P/article/view/14088.

Santoso, M. B., Wibhawa, B., \& Ishartono. (2018). Penerimaan orang tua terhadap anak dengan retardasi mental. Share: Social Work Journal, 8(1), 31-38. http://jurnal.unpad.ac.id/share/article/vie w/16111.

Septiani, D., Meiyani, N., \& Assjari, M. (2010). Pengembangan komunikasi verbal pada anak tunarungu. Jassi Anakku, $\quad$ 9(2), 124-130. 
https://ejournal.upi.edu/index.php/jassi/ar ticle/view/3916/2798.

Septiani, D., \& Nasution, I. N. (2017). Peran keterlibatan dalam pengasuhan bagi perkembangan kecerdasan moral anak. Jurnal Psikologi, 13(2), 120-125. DOI: http://dx.doi.org/10.24014/jp.v13i2.4045.

Sirait A. H., Suriadireja P., \& Sudiarna I.G.P. (2016). Kehidupan penyandang tuna rungu (studi kasus keluarga "KM" di Banjar Celuk, Kelurahan Panjer, Kecamatan Denpasar Selatan). Jurnal Humanis. 17(1), 1-6. https://ojs.unud.ac.id/index.php/sastra/a rticle/view/26450.

Solikhatun, Y. U. (2013). Penyesuaian sosial pada penyandang tunarungu di SLB Negeri Semarang. Educational Psychology Journal, 2(1), 65-72. https://journal.unnes.ac.id/sju/index.php/ epj/article/view/2588.
Wasito, D. R., Sarwindah, D., \& Sulistiani, W. (2012). Penyesuaian sosial remaja tunarungu yang bersekolah di sekolah umum : Studi kasus. Jurnal Psikologi Teori dan Terapan. 2(2), 81-92. DOI: http://dx.doi.org/10.26740/jptt.v2n2.p8 $1-92$.

https://journal.unesa.ac.id/index.php/jp tt/article/view/1843/1249.

Wijanarko, J., \& Setiawati, E. (2016). Ayah ibu baik: parenting era digital. Jakarta: Keluarga Indonesia Bahagia.

Zuhairah, Z., \& Tatar, F. M. (2017). Hubungan antara keterlibatan ayah dalam pengasuhan dengan kenakalan remaja di Kota Banda Aceh. Jurnal Pencerahan, 11(1), 46-52. DOI: https://doi.org/10.13170/jp.11.1.8315. 